\title{
The financialization of US higher education
}

\section{Charlie Eaton*, Jacob Habinek, Adam Goldstein, Cyrus Dioun, Daniela García Santibáñez Godoy, and Robert Osley-Thomas}

\author{
Department of Sociology, University of California, Berkeley, 410 Barrows Hall, Berkeley, CA \\ 94720-1980, USA
}

*Correspondence: charlie.eaton@berkeley.edu

\begin{abstract}
Research on financialization has been constrained by limited suitable measures for cases outside of the for-profit sector. Using the case of US higher education, we consider financialization as both increasing reliance on financial investment returns and increasing costs from transactions to acquire capital. We document returns and costs across four types of transactions: (i) revenues from endowment investments, (ii) interest payments on institutional borrowing by colleges, (iii) profits extracted by investors in for-profit colleges and (iv) interest payments on student loan borrowing by households. Estimated annual funding from endowment investments grew from $\$ 16$ billion in 2003 to $\$ 20$ billion in 2012. Meanwhile financing costs grew from \$21 billion in 2003 to $\$ 48$ billion in 2012 , or from 5 to $9 \%$ of the total higher education spending, even as interest rates declined. Increases in financial returns, however, were concentrated at wealthy colleges whereas increases in financing costs tended to outpace returns at poorer institutions. We discuss the implications of the findings for resource allocation, organizational governance and stratification among colleges and households.
\end{abstract}

Key words: economic sociology, financialization, education, welfare state, institutional change

JEL classification: I22 Educational Finance; Financial Aid, I23 Higher Education, I24 Education and Inequality, N2 Financial Markets and Institutions

\section{Introduction}

Financialization reshapes economic life in industrialized societies by extending the reach of financial markets, logics, and actors into new and varied domains (Epstein, 2005; Krippner, 2011; van der Zwan, 2014). It is well documented that returns on financial investments now account for an increasing share of both corporate and individual incomes (Krippner, 2005, 2011; Orhangazi, 2008; Nau, 2013). Other studies detail the growing role of finance in the management of corporations (Fligstein, 1993, 2001; Zorn et al., 2005), municipalities (Pacewicz, 2013b) and households (Martin, 2002; Langley, 2008; 
Davis, 2009; Fligstein and Goldstein, 2015). While few areas of industrialized economies and societies appear untouched, research has been constrained by limited suitable measures to gauge the extent of financialization outside of the for-profit sector. This, in turn, limits our knowledge of financialization's impacts on important social structures, including systems of social provision that encompass diverse household, non-profit and state institutions.

We address the problem of measuring financialization beyond the for-profit sector by asking how the size and distribution of financial transaction costs and returns have changed for the US higher education system since the beginning of the twenty-first century. Our aims are primarily descriptive. By comprehensively measuring the balance of all major financial transaction costs and returns for different types of organizations over time, we can see both the reach of financialization and key indications of how it allocates resources within the field.

A major contribution of this article is to introduce an original and comprehensive higher education dataset that we have constructed to implement our novel approach to measuring financialization. The rapid growth of student loan debt in the USA is already well known with outstanding student loan balances nearly tripling from \$364 billion in 2004 to $\$ 966$ billion in 2012 (Avery and Turner, 2012; Brown et al., 2014, pp. 3-4; Houle, 2014). By linking annual, college-level data from multiple surveys from 2003 to 2012, however, we are able to estimate the total costs and returns for the four most significant types of higher education financial transactions: (i) revenues from colleges' endowment investment returns, (ii) interest paid on institutional debts by non-profit private and public colleges, (iii) operating profit margins for equity investors in for-profit colleges and (iv) interest paid on student loan debts by households. The institution-level structure of our dataset also allows us to provide new details on the distribution of student loan borrowing and the other major financial transactions across different types and wealth strata of colleges in the USA. We are unaware of any other comparable datasets with comprehensive, institution-level financial transaction data over time for a field that encompasses state, non-profit, for-profit and household organizations.

Analysing our original dataset, we find surprisingly large relative growth in the real value of costs and returns for all four of the major higher education financial transactions. The size and distribution of these increases indicates a multifaceted structural transformation in the financing of US higher education across all major types and wealth strata of state, non-profit and for-profit colleges. All told, the combined real costs from interest for institutional debt, operating margins at for-profits and interest paid on student loans more than doubled from $\$ 21$ billion in 2003 to $\$ 48$ billion in 2012 - an increase from 5 to $9 \%$ of the total higher education spending. ${ }^{1}$ Annual funding for university operations from endowments also grew from \$16 billion to \$20 billion in 2012 constant dollars.

While the increased costs from financial transactions were widespread, funding increases from endowment investments were highly concentrated at a small number of wealthy nonprofit institutions that enrolled relatively few students. Wealthy non-profit institutions also had the largest increases in interest costs for institutional borrowing, but those borrowing costs were far outpaced by funding increases from endowment investment returns. In fact,

1 This number is based on the authors' estimate for total spending on higher education by the state, households and private funders, including money from donors and other sources such research funding. For a full explanation of how we calculate total US higher education spending, see Supplementary material, Appendix. 
high levels of institutional borrowing by the wealthiest institutions indirectly helped them to grow their revenue from endowments by providing funds for capital investments at a lower interest rate than the average endowment rate of return. On the other hand, less wealthy state and non-profit colleges tended to use most of their institutional borrowing for capital projects in areas that generate commercial revenue such as student residential services. Overall, interest for state and non-profit colleges' institutional borrowing nearly doubled from $\$ 6$ billion to $\$ 11$ billion. At the same time, for-profit colleges with capital from equity markets quintupled their annual operating profit margins from $\$ 1$ billion to $\$ 5$ billion.

Despite large increases in financing costs for state, non-profit and for-profit colleges, we find that spending on interest for student loans increased much more. Growth in student loan interest costs was driven by soaring student loan volumes, particularly among students enrolled at for-profit colleges and at less wealthy private and public institutions. As overall student loan volumes increased, annual student loan interest payments grew from $\$ 13$ billion in 2003 to $\$ 34$ billion in 2012. From 2003 to 2012, however, the lowest levels of average borrowing by freshmen were at the wealthiest private colleges where average borrowing actually declined.

Our findings have significant implications for economic sociology and the sociology of higher education, laying the ground for future research. By detailing investment revenue for nonprofit endowments and interest costs for state-funded student loans, we show why financialization should not be viewed as simply a new regime of profit accumulation (Krippner, 2005; Orhangazi, 2008; Nau, 2013). Instead, future studies of potential causes of higher education financialization could ask about the role of professional projects and social ties between colleges and the finance sector. In this vein, future research could also ask why different forms of higher education financialization have or have not occurred in particular countries outside of the USA.

The article proceeds as follows: in the next section, we explain how an analysis of financial revenues and costs can capture the multifaceted nature of financialization in which different actors assume different combinations of roles in financial transactions. We then go on to describe the sources and measures used in our original dataset. The following four sections describe the changes in financial returns and the three main financing costs in turn. Where relevant, we disaggregate different trends across endowment wealth strata and college type. We conclude by further discussing the implications of our findings for future research on financialization and higher education in the USA and elsewhere.

\section{Financialization and higher education}

At the most basic level, financialization is the increasing use of financial transactions to allocate capital. But as actors experience financialization, they assume different roles in financial transactions, including (i) that of an investor (Krippner, 2005; Orhangazi, 2008; Nau, 2013), (ii) that of a borrower (Houle, 2014; Fligstein and Goldstein, 2015) or (iii) that of an investment recipient (Fligstein, 1993). Individual persons and organizations may operate in one or more of these roles.

In most empirical research on financialization, the financial returns to investors overshadow financing costs for borrowers and recipients of investment. ${ }^{2}$ By treating financialization as a

2 For indicators, Krippner uses both measures of profits and corporate cash flow, which is equal to profits minus depreciation allowances which indicate the amount of capital ex pended to accumulate the capital that comprises a firm's profits $(2005$, p. 182). 
pattern of accumulation, this approach highlights profits from financial transactions both within and outside the financial services industry (Arrighi, 1994; Orhangazi, 2008). In the most thorough such account, Krippner $(2005,2011)$ shows that the share of profits going to financial firms increased from between 10 and $20 \%$ in the 1950s and 1960 s to between 30 and $50 \%$ in the early 2000 . At the same time, the share of profits at non-financial firms from interest, capital gains and dividends increased from under $10 \%$ in the 1950 s to over $40 \%$ at the beginning of the 2000 (Krippner, 2005, p. 185).

Although there now exists a growing number of studies of financialization beyond the corporate sector (Martin, 2002; Langley, 2008; Davis, 2009; Pacewicz, 2013a,b), quantitative work has lagged. In large part, this is due to the absence of comparable measures for financialization besides profit accumulation. We address this problem in existing research by developing a new approach for measuring financialization in both the costs and returns incurred by actors through their different roles in multiple types of financial transactions.

The US higher education system provides a valuable case for assessing the reach of financialization as a multi-faceted process. The USA is unusual among national higher education systems in its high degree of organizational heterogeneity, including state-owned, private nonprofit and for-profit colleges. With their complex and varied reliance on state, commercial and investment revenue, educational providers assume varying roles in financial transactions depending on the college's ownership form and existing wealth. Despite this organizational diversity, there is an exceptional amount of untapped data for the use of financial transactions across all types of US colleges. This wealth of data presents us with an opportunity to systematically assess the change in the size and distribution of financial costs and returns within a hybrid system of social provision that includes both public and private service providers (Hacker, 2002; Morgan and Campbell, 2011).

\subsection{Returns and costs of financialization}

To document the extent of financialization in a mixed domain of social provision such as higher education, we adopt a straightforward approach to measuring financialization across multiple roles. We replace measures of financially generated profits with a more general measure of financially generated revenues, and supplement it with measures of financing costs stemming from borrowing and equity investment. This method builds on the existing accumulation approach by measuring both the share of revenues that are generated from financial activities, as well as the share of expenditures that are directed toward financing costs.

By financing costs we mean the gross costs associated with acquisition of liquid capital. Our approach proceeds from the idea that the significance of finance increases when actors acquire a greater share of resources from the provision of capital, and when they devote a greater share of expenditures to the acquisition of capital. Financiers provide recipients with capital in order to fund a given use (in our case, investments by educational consumers and educational providers). Such financing may take the form of debt or equity. In return, financiers seek income from interest, dividends or capital gains. Payments of interest to creditors and profits to equity investors represent the resulting financial costs. In the aggregate, financial returns and costs can be seen as two sides of the same coin; an increase in financial profits implies an increase in financial costs paid by recipients of capital.

Our approach has several additional advantages for studying financialization across different types of organizations. First, it encompasses a wider array of transactions. For example, households devote a growing portion of their total educational expenditures to interest 
payments on student loans. As the largest creditor for student loans, the federal government receives substantial revenue from these payments, but the federal government does not accumulate profits from this income in a way that is commensurable with profits accumulated by private financiers. Nevertheless, student loan interest payments provide a useful measure of financialization as experienced both by households in a borrowing role and by the government in a lending role.

Second, our approach is sensitive to the fact that given organizations can operate in more than one of the roles of investor, borrower or investment. This means that they accrue revenues from financial transactions at the same time that they pay financing costs to acquire capital. It is important to adopt an analytical approach that is attentive to both sides of this equation. As we show below, some universities have become simultaneously both increasingly reliant on financially generated income from endowments and more indebted, with corresponding increases in the portion of their total expenditures dedicated to servicing these debts. By attending to the costs and returns from all three of the primary financial transaction roles, our approach more fully gauges the extent of financialization in a given organization or field.

\subsection{Higher education finance in the USA}

Scholarship on markets and higher education in the USA has shown that colleges and universities earn revenue from complex and multi-layered sources, including state subsidies, tuition, charitable donations, capital gains and commercial activities (Slaughter and Leslie, 1997; Winston, 1999; Ehrenberg, 2000). The US colleges are commonly grouped into four 'sectors' based on their ownership and highest level of degree offered: (1) public colleges and universities are state owned and almost never offer less than 4-year degrees, (2) community colleges are state owned and offer no higher than 2-year degrees, (3) private colleges are non-profit and almost never offer less than 4-year degrees and (4) proprietary colleges have for-profit ownership and vary in offering less than 2-year certificates, 2-year degrees, 4-year degrees or combinations of all three (Deming et al., 2012). Figure 1 shows that full time equivalent enrolment grew substantially across all four sectors from 1997 to 2012. Degree programs, research and other activities across all of these diverse public, non-profit and forprofit organizations require transfers, investment and borrowing transactions among an array of funders, suppliers and consumers. Accordingly, any account of financialization in higher education must take account of its multiple levels and heterogeneous subsectors.

The rise of a market orientation in higher education parallels the decline in direct state appropriations for colleges and universities (Slaughter and Leslie, 1997). State appropriations and direct federal funding paid for the massive expansion of US higher education from 1962 to 1972 when enrolment tripled from 4 million to 12 million students (Rhoades, 1990, p. 194; Brown-Collier, 1998, p. 270). But most federal funding for undergraduate education since the 1970s has been channelled to colleges through markets: the federal government has provided funding to students rather than to colleges. Students then choose an institution to which they will apply federal-aid funds. For most public universities, both the share of direct funding coming from state governments and the total state funding per student have also declined since 1990 (Quinterno, 2012; Weerts et al., 2012).

Nearly all USA colleges and universities must generate commercial revenues to fund operations. But at selective private colleges and universities, education costs have tended to increase much faster than inflation because these schools compete primarily to maximize their prestige (Winston, 1999; Ehrenberg, 2000). As such, there has been little incentive for selective colleges 


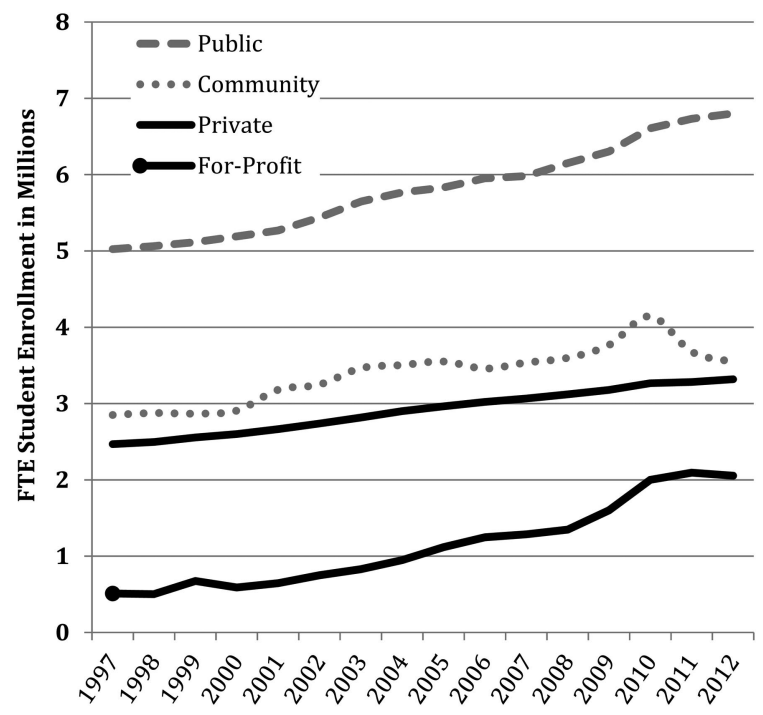

Source: IPEDS.

Figure 1. Enrolment by sector.

to control costs, absent state intervention. Non-selective public colleges, however, have also increased tuition as well as room and board costs much faster than the average income or state-funded grant aid in order to compensate for reductions in federal and state appropriations (Quinterno, 2012; Weerts et al., 2012). Proprietary colleges have meanwhile seized on federal student-aid programs to increase their profits (Mettler, 2014). Together, these dynamics have increased the costs which colleges pass on to students, even if colleges use state or charitable resources to subsidize degree programs.

Colleges of all types also make capital investments to remain competitive in these markets for commercial revenues. Research universities compete for federal and private research funding, and therefore invest in facilities such as research centres, joint research ventures and hospitals (Powell and Owen-Smith, 1998; Geiger, 2004, 2006). Residential colleges invest in revenue-generating services and amenities like dormitories, dining halls and college sports in order to develop new income streams as well as to attract students willing to pay higher tuition and fees (Slaughter and Leslie, 1997; Armstrong and Hamilton, 2013; Jacob et al. 2013). Although some states and municipalities issue public bonds on behalf of schools, especially community colleges, the majority of higher education organizations are responsible for acquiring most of their own capital to fund infrastructure, facilities and other investments.

Different types of colleges and universities have different institutional origins and assume different organizational forms (Stevens et al., 2008), with large variations in assets, income and sources of capital. Four-year public colleges receive support from a mixture of sources: state appropriations, endowments, student tuition, research funding and auxiliary services such as dormitories, sports programs and hospitals. In 2012, the 331 public college systems in the USA enrolled well over 6 million or $41 \%$ of all enrolled, full-time equivalent (FTE) 
students. ${ }^{3}$ Four-year private colleges typically do not receive direct state funding, but otherwise compete for the same sources of support as public colleges. Private colleges enrolled over 3 million or $21 \%$ of FTE students at 1641 systems or independent institutions. The 2-year community colleges receive state appropriations, but have very limited access to funding for research and auxiliary services. The 819 community college systems enrolled over 4 million or $27 \%$ of FTE students. Proprietary colleges lack access to many of the financial channels available to non-profit colleges, but do have access to federally financed student loans and equity investment from the stock market or private equity. Proprietary colleges enrolled under 2 million or $10 \%$ of FTE students at 1320 colleges. Together, these four sectors enrolled $99 \%$ of all FTE students at 2-year or above colleges in $2012 .{ }^{4}$

Consistent with their organizational heterogeneity, colleges have access to different forms of capital with different types of financing costs, depending on their sector and the activities they seek to capitalize. Public, community and private colleges can establish endowments, the income from which is exempt from taxation. They can also borrow using tax-exempt municipal bonds, notes, capital leases and commercial paper. These funds pay for capital projects such as research facilities, hospitals, dormitories and athletic centres. State or local governments can issue municipal bonds on behalf of public, community or private colleges, but public and community colleges increasingly issue bonds directly. In either case, colleges must pay interest for such debts as a financing cost.

In contrast, proprietary colleges are not eligible to run tax-exempt endowment funds, or to raise capital through municipal bonds. Instead, proprietary colleges raise capital through equity markets and corporate borrowing. Proprietary colleges may invest this capital in capital projects, upgrades or their intensive spending on advertising and marketing. Equity capital may entail either public stock offerings or investments by private equity firms. The financing cost of raising such capital is the profits that such proprietary colleges earn to satisfy their equity investors.

As we document below, financialization has occurred across all four subsectors, but in different ways and to varying extents. One commonality across all four sectors is a growing burden of educational expenditures on households. With aspirations for the higher wages and the status promised by a college degree, students and their households have therefore increasingly relied on student loans to pay for rising college costs (Avery and Turner, 2012).

In addition to their other roles, colleges also function as financial intermediaries by connecting student borrowers and financial lenders. College financial aid offices arrange custom, individualized student aid and loan packages for households to purchase degree programs. In some cases, particularly in the for-profit sector, colleges have also acted as a private student loan lender to their own students (Consumer Financial Protection Bureau and US Department of Education, 2012). Student loan lending by colleges is rare, however, and we are unaware of any accessible data on the extent of lending by colleges. To the extent that colleges' pass their financial aid administration costs on to students, those costs would be included in the amount

3 We aggregate all data for colleges up to the level of a college system when a college shares any financial functions like debt issuance with an administrative office or parent institution.

4 We do not examine 2-year private colleges because they enrolled just 1\% of all FTE students in 2012. We do, however, include them in calculating enrolments and spending for all higher education at 2-year-and-above colleges. 
borrowed by students. As such, it is appropriate to maintain our focus on the overall amount of student loan borrowing and the cost of interest for these loans to households.

In borrowing to finance educational costs, households have increasingly borrowed directly from the federal government, underscoring the important role that the state can play in financialization as a lender itself. Between 1993 and 2010, households could borrow for higher education expenses using three main different types of loans: federally funded student loans, loans funded by private banks but guaranteed by the government Federal Family Education Loan (FFEL) program, and private student loans issued by banks without a federal guarantee. However, the US Congress halted the origination of privately funded FFEL loans in 2010, and lending by banks without a federal guarantee collapsed after the 2008 financial crisis. As a result, loans funded directly by the federal government have come to make up nearly $90 \%$ of new loan origination since 2010 .

While the radical increase in student loan borrowing is well documented, existing scholarship has yet to account for how rising student loan interest and other higher education finance costs have figured in the overall trajectory of higher education costs. We provide findings to that effect below. Before presenting these findings, however, we will first explain how we selected appropriate measures in each case. We will also detail how we assembled comprehensive data for those measures.

\section{Data and measures}

We gauge financialization in higher education by tracking the use of four key financial transactions for acquiring and investing capital: (i) investment returns from college endowments, (ii) institutional borrowing by colleges, (iii) equity investment in for-profit colleges and (iv) student loan borrowing by student households. Our data includes only those colleges that grant 2-year degrees or higher and are eligible for funding under Title IV of the federal Higher Education Act. ${ }^{5}$ For this paper, we created a dataset for higher education financing costs and related organizational variables based on Integrated Postsecondary Education Data System (IPEDS) historical data for all such institutions, which we have harmonized with other datasets.

\subsection{Financial revenues from endowments}

We use data on endowment asset values, returns and funding of university operations for 4-year public and non-profit institutions from both IPEDS (National Center for Education Statistics, 2014) and NACUBO. As a professional organization for college business and finance officers, NACUBO has collected detailed data on endowment asset levels, investment returns and spending on college operations from endowment funds (2013). By harmonizing NACUBO data with IPEDS data, we were able to obtain data for endowment assets for all years from 2003 for 209 public systems and 871 private systems. This provides us with full endowment data for $68 \%$ of all undergraduate-enrolling public systems. We have the same coverage for $69 \%$ of private systems. This is the most complete dataset for endowment

5 We limit our analysis to only these colleges because this paper relies heavily on data from the US Department of Education's Integrated Post-Secondary Education Data System (IPEDS), which only collects information for Title IV eligible institutions. Accredited colleges that are less-than-2-year institutions enrolled less than $2 \%$ of the 21 million post-secondary students in the USA in 2012, and an even smaller share of FTE students. 
assets that we know of, and it is likely that many of the institutions for which we lack data do not actually operate endowments with substantial assets.

We also use NACUBO data on the amount of funding provided by endowments for spending on university operations and programs every year. This is the best available measure of the resources that endowments actually provide to colleges for higher education activities. Measures of allocations for operations from endowments is much better than the amount of annual investment returns which are extremely volatile, swinging from positive returns to net losses from 1 year to the next. This measure is also better than rolling multi-year averages of investment returns because it reflects the actual planning and options available for allocating resources. The number of public, undergraduate-enrolling systems for which we have data on spending from endowments ranges from 117 in 2003 to 132 in 2012. Such data for private systems ranges from 377 systems in 2003 to 434 in 2009. For the remaining public and private systems for which we have full endowment asset value data for all years, we estimate spending from endowments by using the average endowment spending rate for the institutions' sector for the given year. For further details, see Supplementary material, Appendix.

\subsection{Interest costs for institutional debts}

For publics and non-profits, we calculated the total annual gross costs of institutional debt using data from IPEDS. This is measured as the total annual expenditure on interest payments. The number of public undergraduate-enrolling systems for which such data are available ranges from 182 or $59 \%$ of such systems in 2003 to 211 or $69 \%$ in 2012 . It is not known what share of the remaining systems actually issue their own debt as opposed to receiving capital projects funding financed by borrowing or appropriations by state governments, local governments, tribal authorities or by federal appropriations in the case of military institutions. The number of private undergraduate-enrolling systems for which such data are available ranges from 806 or $62 \%$ of such systems in 2003 to 850 or $65 \%$ in 2012 . As in the case of endowments, we use IPEDS data on total spending by college to calculate spending on interest for institutional debts as a share of total spending by colleges.

\subsection{Equity investment in proprietary colleges}

Within the for-profit subsector, equity financing is the primary means of acquiring capital investment. Because data on the distributions of profits to investors do not exist, we instead measure the operating surplus of those proprietary colleges which have received capital from stock offerings or private equity. ${ }^{6}$ We do so by taking the net revenues from operations and subtracting the costs of providing services (i.e. instructional spending), as well as general administrative/overhead costs, depreciation/amortization and marketing costs. Operating profits are a useful proxy for the financial costs of using equity capital because they capture the difference between household and government expenditures on education, on the one hand, and the costs incurred by the provider firms, on the other hand.

We also account for differences among for-profit colleges across ownership forms. This is the first paper to take this factor into account by using data collected by the authors in

6 Since most for-profit colleges do not report any non-operating income, operating profit is synonymous with EBIT (earnings before interest and taxes). 
order to code the 7000 plus Title IV eligible for-profit colleges from 1997 to 2013 by the ownership form of each college's parent company. In doing so, we are able to distinguish profit growth of for-profit colleges by closely held, publicly traded and private equity financed firms. The aggregate figures reported below represent the sum of firm-level figures for 28 publicly traded higher education companies from 1997 to $2012,{ }^{7}$ as well as 81 college firms owned by private equity firms during the same period (company profits are only included during years when the company was publicly traded or owned by private equity).

By comparing operating margins reported in IPEDS with the income sheets of fiscal year-end $10-\mathrm{K}$ statements for publicly traded firms, we determined that operating margins reported in IPEDS accurately reflect the actual operating margins of for-profit colleges. We therefore used IPEDS data to calculate comparable operating margin measures for all forprofit colleges by using revenue and expenditure figures reported in IPEDS. ${ }^{8}$

\subsection{Interest costs for student loans}

For both federal and private student loans, we provide the first publicly available estimates of which we are aware for annual interest paid by the loan type. In doing so, we estimate the annual financing costs for households to pay for higher education.

Interest payments on private student loans and Federal Family Education Loans (FFEL), the largest area of student loan origination prior to 2010, have never been tracked at any level to our knowledge. To address this inadequacy, we used data on annual student loan origination by the loan type from the College Board (2013), the annual interest rates for each student loan type and also the average time in deference and in repayment for student loans overall to estimate annual interest payments for each student loan cohort by the loan type. For each year, the total student loan interest payments by loan type are the sum of payments across all cohorts, reported in constant 2012 dollars. The sources for the multiple data points used to estimate annual interest payments are discussed in detail in Supplementary material, Appendix.

With the available data, student loan interest payments cannot be disaggregated by a sector or college. Nor can interest payments across the higher education system be estimated well prior to 2003. The College Board, however, has published annual totals of all student loan origination since 1972 and totals for student loan origination by sector since 1993. Because loan origination levels have been the most decisive factor in student loan interest costs, we use the College Board data to assess earlier phases in student loan financialization than the transformation since 2003.

Again for the first time that we are aware, we calculate annual student loan borrowing by full-time freshmen by both sector and cross-classifications of endowment wealth levels since 2003 (the first year for which we have adequate endowment data). We were able to do so having harmonized data from IPEDS and NACUBO.

7 These include American Public Education, Apollo, Bridgepoint, Capella, Career Education Corp., Corinthian, DeVry, EDMC, Grand Canyon, ITT, Kaplan (see note 12 below), Lincoln, National American University, Strayer and Universal Technical. Most of these publicly traded firms operate multiple college brands.

8 We matched individual campus records in the IPEDS data by institutional affiliation, and subtracted total expenses from total current funds revenues. 
In the next section, we will describe the size and distribution in the increase of endowmentfunded expenditures as a share of all higher education expenditures. Then, we detail the size and distribution of increases in spending per student on the three principal financing costs for acquiring capital in the US higher education system.

\section{College endowments and financial revenues}

Endowments play an increasing role in financing US higher education. Since the 1980s, more institutions have sought to build endowments and thereby assume the role of financial investors. NACUBO reports show that just 148 undergraduate-enrolling systems reported operating endowments to NACUBO in 1977 and just 36 of them were public. ${ }^{9}$ By 2009, the number of public systems reporting endowments had grown to 158 , with an increase to 501 for undergraduate-enrolling systems overall. The total endowment asset values reported by NACUBO increased 10-fold in 2012 constant dollars from $\$ 39.8$ billion in 1977 to a high of $\$ 456$ billion in 2007. From 2003 to 2012, when more detailed data are available, assets at public institutions doubled from $\$ 61$ to $\$ 122$ billion, while private college endowment assets grew by $49 \%$ from $\$ 201$ billion to $\$ 300$ billion, Together with fundraising, investment returns provided for net growth of both public and private endowments.

\subsection{The concentration of endowment assets}

Although the use of endowments has diffused to less wealthy colleges, the growth in asset values has been concentrated disproportionately at the wealthiest institutions (Piketty, 2014, p. 448). Among the nine undergraduate-enrolling private institutions that held more than 1 billion dollars in endowment assets in 1977, the total endowment assets of more than quadrupled from $\$ 17.2$ billion in 1977 to $\$ 77.8$ billion in 2003, an average of 594 thousand dollars in assets per FTE student. Using more detailed data for years since 2003, we find that the exponential growth of endowment assets has continued among the wealthiest institutions. Table 1 shows endowment asset values and FTE enrolments of all students at undergraduate-enrolling public and private 4-year systems by quantiles for endowment wealth in 2003, 2007 and 2012. The figures in the table are based only on those institutions that reported endowment asset values in every year, so the trends are not driven by compositional changes in the sample population. All quantiles in the table based on 2003 endowment asset values.

The increasingly skewed distribution of endowment assets is most apparent when considered on a per student basis. Public endowments assets per FTE student grew by $73 \%$ from $\$ 7600$ to $\$ 18800$, while private college endowment assets per FTE student grew by 25 percent from $\$ 71300$ to $\$ 89500$. The weighted mean endowment asset values per student at public systems between the 50th and 89th percentile was just $\$ 13.7$ thousand in 2012, only $\$ 3.9$ thousand higher than in 2003. In contrast, endowment asset values per student for the eight private institutions in the 99th percentile were $\$ 886$ thousand in 2012, \$178 thousand higher than 2003 levels. In 2012, these nine institutions controlled $27 \%$ of all endowment assets, but enrolled around 1\% of FTE students attending public and private schools.

9 At present, the authors lack annual machine-readable data on endowments prior to 2003. 
Table 1. Endowment asset measures by sector and percentiles for 2003 endowment wealth

\begin{tabular}{|c|c|c|c|c|c|c|c|}
\hline & & \multicolumn{3}{|l|}{ Public } & \multicolumn{3}{|l|}{ Private } \\
\hline & & $\begin{array}{l}0-89 \text { th } \\
\text { Percentile }\end{array}$ & $\begin{array}{l}\text { 90-98th } \\
\text { Percentile }\end{array}$ & $\begin{array}{l}\text { 99th } \\
\text { Percentile }\end{array}$ & $\begin{array}{l}0-89 \text { th } \\
\text { Percentile }\end{array}$ & $\begin{array}{l}\text { 90-98th } \\
\text { Percentile }\end{array}$ & $\begin{array}{l}\text { 99th } \\
\text { Percentile }\end{array}$ \\
\hline \multirow[t]{4}{*}{2003} & Institutions & 194 & 19 & 2 & 784 & 79 & 8 \\
\hline & $\begin{array}{l}\text { Total } \\
\text { endowment } \\
\text { assets }^{\dagger}\end{array}$ & $\$ 29.4 \mathrm{~B}$ & $\$ 34.3 \mathrm{~B}$ & $\$ 21.6 \mathrm{~B}$ & $\$ 39.5 \mathrm{~B}$ & $\$ 84.2 \mathrm{~B}$ & $\$ 80.1 \mathrm{~B}$ \\
\hline & Total enrolment & 3748328 & 1220786 & 330124 & 1604254 & 513737 & 113118 \\
\hline & $\begin{array}{l}\text { Endowment } \\
\text { assets per } \\
\text { student }\end{array}$ & $\$ 7841$ & $\$ 28134$ & $\$ 65475$ & $\$ 24635$ & $\$ 163855$ & $\$ 707925$ \\
\hline \multirow[t]{4}{*}{2007} & Institutions & 194 & 19 & 2 & 784 & 79 & 8 \\
\hline & $\begin{array}{l}\text { Total } \\
\text { endowment } \\
\text { assets }^{\dagger}\end{array}$ & $\$ 50.8 \mathrm{~B}$ & $\$ 57.9 \mathrm{~B}$ & $\$ 33.7 \mathrm{~B}$ & $\$ 57.5 \mathrm{~B}$ & $\$ 129.4 \mathrm{~B}$ & $\$ 131.4 \mathrm{~B}$ \\
\hline & Total enrolment & 3941821 & 1307892 & 355761 & 1763605 & 549666 & 118225 \\
\hline & $\begin{array}{l}\text { Endowment } \\
\text { assets per } \\
\text { student }\end{array}$ & $\$ 12879$ & $\$ 44232$ & $\$ 94609$ & $\$ 32628$ & $\$ 235437$ & $\$ 1111215$ \\
\hline \multirow[t]{4}{*}{2012} & Institutions & 194 & 19 & 2 & 784 & 79 & 8 \\
\hline & $\begin{array}{c}\text { Total endowment } \\
\text { assets }^{\dagger}\end{array}$ & $\$ 49.7 \mathrm{~B}$ & $\$ 57.1 \mathrm{~B}$ & $\$ 34 . \mathrm{B}$ & $\$ 50.8 \mathrm{~B}$ & \$113. B & $\$ 113.8 \mathrm{~B}$ \\
\hline & Total enrolment & 4400779 & 1468703 & 400452 & 1958368 & 597768 & 128440 \\
\hline & $\begin{array}{l}\text { Endowment } \\
\text { assets per } \\
\text { student }\end{array}$ & $\$ 11304$ & $\$ 38873$ & $\$ 84996$ & $\$ 25930$ & $\$ 189016$ & $\$ 885953$ \\
\hline
\end{tabular}

Source: IPEDS and NACUBO.

Note: Community-college-only systems, military institutions and institutions that do not enrol undergraduates are excluded. Percentiles are for institutions' endowment wealth in 2003 and are calculated for each sector separately. Endowment assets per student are total endowment assets for the quantile over total FTE students for the quantile. B, billion.

${ }^{\dagger}$ Total endowment assets are in billions.

\subsection{Endowment returns and spending on college operations}

As wealthy universities saw their investment assets grow, they also spent increasing amounts of investment-generated income to fund operations. Concretely, endowment investment returns provide resources for higher education through annual allocations from endowments for higher education activities. From 2003 to 2012, the mean percentage of endowment assets allocated for college and university operations ranged from 4 to $5 \%$ annually among all public systems and among private institutions below the 90 th percentile of wealth. Average spending rates from endowments among institutions in the top two quantiles of private institutions ranged between 4.4 and $6.2 \%$, increasing as endowments reported large losses from the global financial crisis in the 2009 fiscal and academic year.

Given the stratified distribution of financial assets documented above, we can expect that the reliance on financially generated revenues would also be uneven. Figure 2 shows the actual 


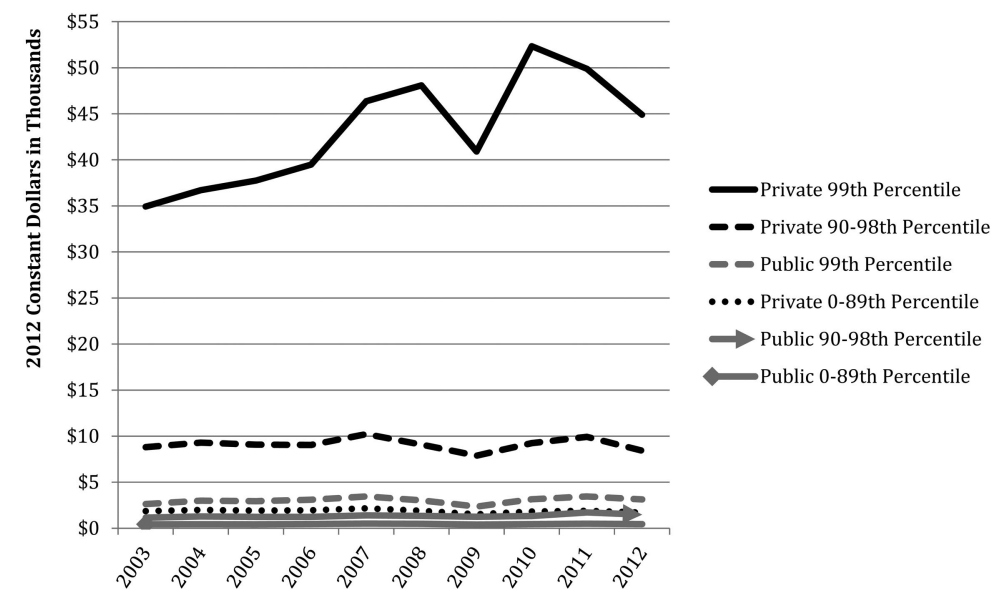

Source: IPEDS and NACUBO.

Note: Community-college-only systems, military institutions and institutions that do not enroll undergraduates are excluded.

Quantiles are for institutions' endowment wealth in 2003 and are calculated for each sector separately. Spending per student is the total spending for the quantile over the total FTE student enrollment per quantile.

Figure 2. Spending per student from endowments on college operations by sector and 2003 endowment wealth quantiles.

spending per student from endowments on college operations by quantiles of 2003 endowment wealth. From 2003 to 2008, spending from endowments per student at private universities in the 99th percentile increased from $\$ 34900$ to $\$ 48100$. This represents an increase from 19.5 to $24.3 \%$ of those institutions' total expenditures. When the global financial crisis caused massive losses for these institutions in the fall of 2008, these colleges actually increased the share of endowment assets spent on operations. Spending from endowments by the top $1 \%$ of colleges reached a new high of $\$ 52.3$ thousand per FTE student in 2010 .

In contrast, financially generated revenues played a very limited role in funding those institutions in the bottom $99 \%$ of public colleges and those in the bottom $90 \%$ of private institutions. These non-beneficiaries of endowments, however, together enrolled 7.9 million or $98 \%$ of FTE students at institutions with full endowment data. In short, revenues from financial channels played a growing role in funding higher education, but this was confined to the wealthiest institutions.

\section{College institutional debt and interest costs}

Municipal bonds are the primary instrument by which public and private non-profit colleges issue debt. Higher education bonds may be issued by states, by local governments or-in an increasing number of cases-by higher education institutions themselves. Money raised on bond markets customarily goes to finance capital improvements, including classroom construction, new dormitories and physical plant maintenance. Bonds may be secured by pledges ranging from the full faith and credit of the issuing entity to more limited pledges of state or local appropriations, ad valorem property taxes, or revenues from projects built using proceeds from the bond. 


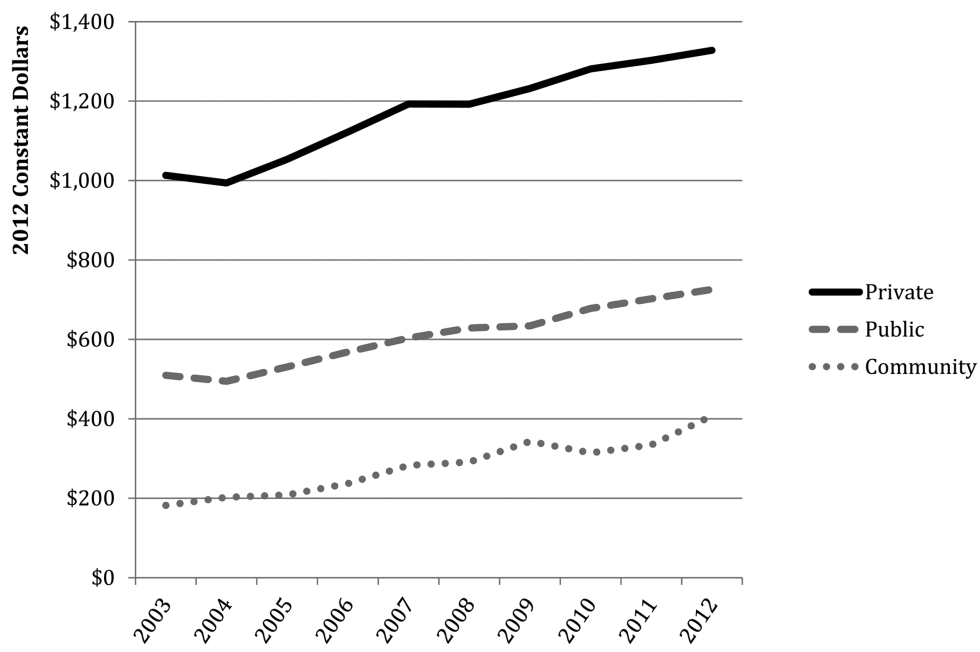

Source: IPEDS

Note: Spending per student is the total spending for the sector over the total FTE student enrollment for the sector.

Figure 3. Spending per student on interest for institutional debt by sector.

Public, private and community colleges have all taken on increasing amounts of municipal bond debt since at least 2003. Using IPEDS data, we find that public and community college debt more than doubled from $\$ 73$ billion to $\$ 151$ billion over the last decade. ${ }^{10}$ IPEDS does not report debt levels at private colleges before 2010, but in 2012 private college debt stood at $\$ 95$ billion. Interest payments on institutional debt are available since 2003 for all college types; these have nearly doubled from $\$ 6$ billion to $\$ 11$ billion. ${ }^{11}$ Average spending on institutional debt rose faster than enrolments at community, public and private colleges alike, and spending also grew across all levels of endowment wealth strata, although at much faster rates for the wealthiest $1 \%$ of private colleges.

\subsection{The financing costs of institutional debt}

Debt financing costs have grown across private, public and community colleges. Figure 3 shows the weighted mean spending per student on interest payments by sector. From 2003 to 2012, public colleges' annual spending on interest payments per FTE student increased by $45 \%$, from $\$ 519$ in 2003 to $\$ 750$ in 2012 . Interest costs per student for private 4-year colleges increased $23 \%$, from $\$ 1,047$ to $\$ 1,289$. Interest costs per student at community colleges, however, increased to $76 \%$, from $\$ 222$ to $\$ 390$.

These increases in spending on interest are primarily due to increased borrowing. They cannot be explained by increases in either interest rates or enrolment. According to all available measures, the total interest payments have increased even as interest rates have fallen.

10 Comparable historical numbers are not available from private colleges during this period. Data on debt for private colleges is only available beginning in 2010. In 2012 their debt amounted to an additional $\$ 95$ billion, up from $\$ 91$ billion in 2010 .

11 Adequate data are not available to measure institutional debt prior to 2003. 
Further, the growth of college and university debt payments has far outpaced growth in enrolments across all sectors.

\subsection{Institutional debt and endowment assets}

Figure 4 breaks down interest expenditures by endowment asset quantiles. Interest costs per student increased by substantially larger amounts at wealthier private and public institutions. Spending on interest costs as a share of all institutional spending also increased fastest at wealthy private and public institutions, doubling between 2003 and 2012 for the top percentile of both public and private institutions. This transformation was most dramatic at Harvard, Princeton and Yale, the three wealthiest private institutions. Spending on interest at these three institutions increased from $3.0 \%$ of all spending in 2003 to $7.0 \%$ in 2011 before declining slightly in 2012 to $6.6 \%$. The interest spending rate increased from 2.3 to $3.3 \%$ across all private institutions in the 99 th percentile. The rate increased from 1.1 to $2.4 \%$ at the 99 th percentile of public systems for endowment wealth. All other quantiles saw a positive but smaller change in this rate.

The rapid growth in financing expenditures at the wealthiest institutions initially appears puzzling. These wealthy, high status institutions could have afforded to pay for capital projects with endowment assets, and enjoyed lower marginal borrowing costs. Endowment investments, however, yielded higher rates of return than prevailing interest rates for bond debt. So, taking on debt to fund all kinds of capital projects is much cheaper than dipping into endowments or donor gifts (Congressional Budget Office, 2010). By leveraging their strong credit ratings, wealthy institutions could use inexpensive debt to effectively maximize their overall financial returns.

Table 2 shows the net balance between funding for university operations from endowments and institutional debt interest costs. This net balance is calculated by simply subtracting each institution's total interest costs per student from its total spending on college operations from endowments per student. The 99th percentile of private institutions increased this net

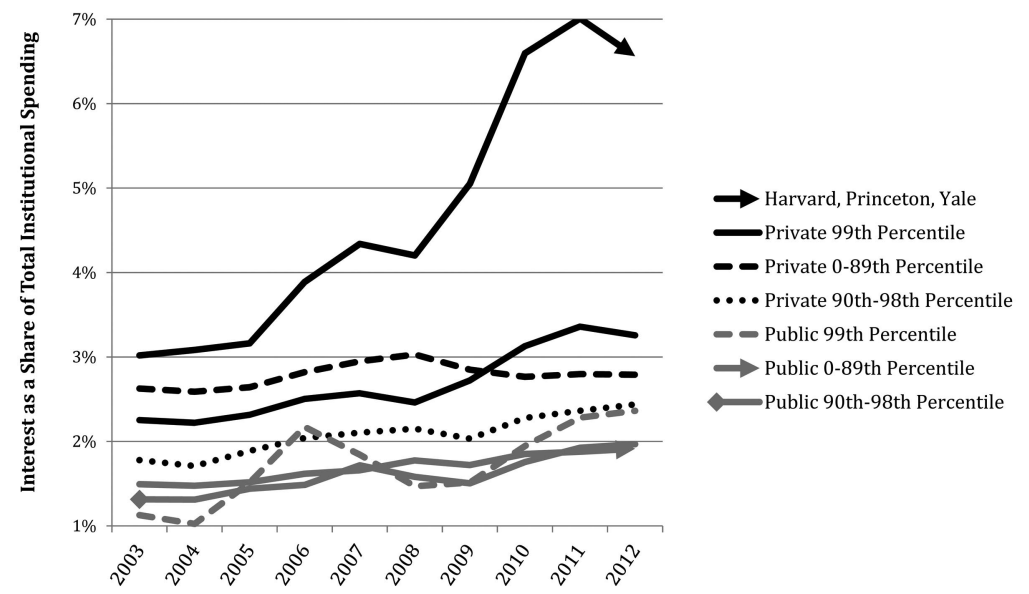

Source: IPEDS.

Notes: Military institutions and institutions that do not enroll undergraduates are excluded. Quantiles are for institutions' endowment wealth in 2003 and are calculated separately for each sector. Interest share is calculated as the total interest spending for the quantile over the total overall spending for the quantile.

Figure 4. Interest as a share of total institutional spending by sector and 2003 endowment wealth quantiles. 
Table 2. Per student balance of spending from endowments and interest costs For institutional debts

\begin{tabular}{|c|c|c|c|c|c|c|}
\hline & \multicolumn{3}{|l|}{ Public } & \multicolumn{3}{|l|}{ Private } \\
\hline & $0-89$ th & 90-98th & 99th & $0-89$ th & 90-98th & 99th \\
\hline & Percentile & Percentile & Percentile & Percentile & Percentile & Percentile \\
\hline 2003 & $-\$ 63$ & $\$ 718$ & $\$ 1259$ & $\$ 1100$ & $\$ 6900$ & $\$ 30887$ \\
\hline 2004 & $-\$ 66$ & $\$ 826$ & $\$ 1705$ & $\$ 1279$ & $\$ 7385$ & $\$ 32629$ \\
\hline 2005 & $-\$ 71$ & $\$ 735$ & $\$ 1419$ & $\$ 1195$ & $\$ 6998$ & $\$ 33361$ \\
\hline 2006 & $-\$ 58$ & $\$ 668$ & $\$ 1379$ & $\$ 1227$ & $\$ 6861$ & $\$ 34642$ \\
\hline 2007 & $-\$ 19$ & $\$ 753$ & $\$ 1711$ & $\$ 1379$ & $\$ 7837$ & $\$ 41302$ \\
\hline 2008 & $-\$ 77$ & $\$ 707$ & $\$ 1386$ & $\$ 1085$ & $\$ 6718$ & $\$ 43221$ \\
\hline 2009 & $-\$ 193$ & $\$ 412$ & $\$ 821$ & $\$ 728$ & $\$ 5398$ & $\$ 35061$ \\
\hline 2010 & $-\$ 159$ & $\$ 451$ & $\$ 1289$ & $\$ 1107$ & $\$ 6987$ & $\$ 45770$ \\
\hline 2011 & $-\$ 132$ & $\$ 650$ & $\$ 1275$ & $\$ 1178$ & $\$ 7622$ & $\$ 42856$ \\
\hline 2012 & $-\$ 192$ & $\$ 415$ & $\$ 853$ & $\$ 904$ & $\$ 5968$ & $\$ 37846$ \\
\hline
\end{tabular}

Source: IPEDS and NACUBO.

Note: Community-college-only systems, military institutions and institutions that do not enrol undergraduates are excluded. Quantiles are for institutions' 2003 endowment wealth and are calculated for each sector separately. Per student balance of spending is the total balance of endowment spending minus interest costs for the quantile over total FTE enrolment for the quantlie.

balance per student from $\$ 30800$ in 2003 to $\$ 37800$ in 2012, peaking at $\$ 45.8$ thousand in 2010. This net balance declined for all other quantiles over the full period. ${ }^{12}$

Wealthier institutions tended to spread borrowing more widely across multiple purposes including prestige-boosting investments in instruction and research. Among less wealthy private institutions, however, we can see that the largest and fastest increases in institutional debt costs were for capital investments in the financial reporting categories of auxiliary and student services that include student amenities. Such amenities include dormitories, cafeterias, stadiums, college athletics and recreation centres. ${ }^{13}$ Figure 5 shows that interest costs for the category including amenities rose faster and more consistently than interest costs for any other

12 The net balance for 90 th to 98 th percentile of private institutions declined from $\$ 7212$ to $\$ 6278$. The net balance for public institutions above the 90th percentile and private institutions in the 50th to 89th percentiles all declined by at least $22.5 \%$ but remained positive, having started in 2003 at around $\$ 1000$ per student. The net balance between funding from endowments and interest spending was negative throughout the period for the bottom $90 \%$ of public systems and the bottom $50 \%$ of private institutions, declining to less than negative $\$ 209$ for the former and negative $\$ 139$ for the latter.

13 We adopt the same approach here as Jacob et al. in grouping auxiliary services and student services together as the categories that include amenities spending. The overwhelming majority of spending on interest for these categories is for auxiliary services. It should be noted that auxiliary services can include activities that are not generally considered as amenities, such as research parks. The large shares of interest spending in auxiliary services as less wealthy public and private institutions, however, suggests that the type of amenities we discuss are at greater play than research park enterprises. Student services, on the other hand, can also include spending on improved student academic and career counselling. 

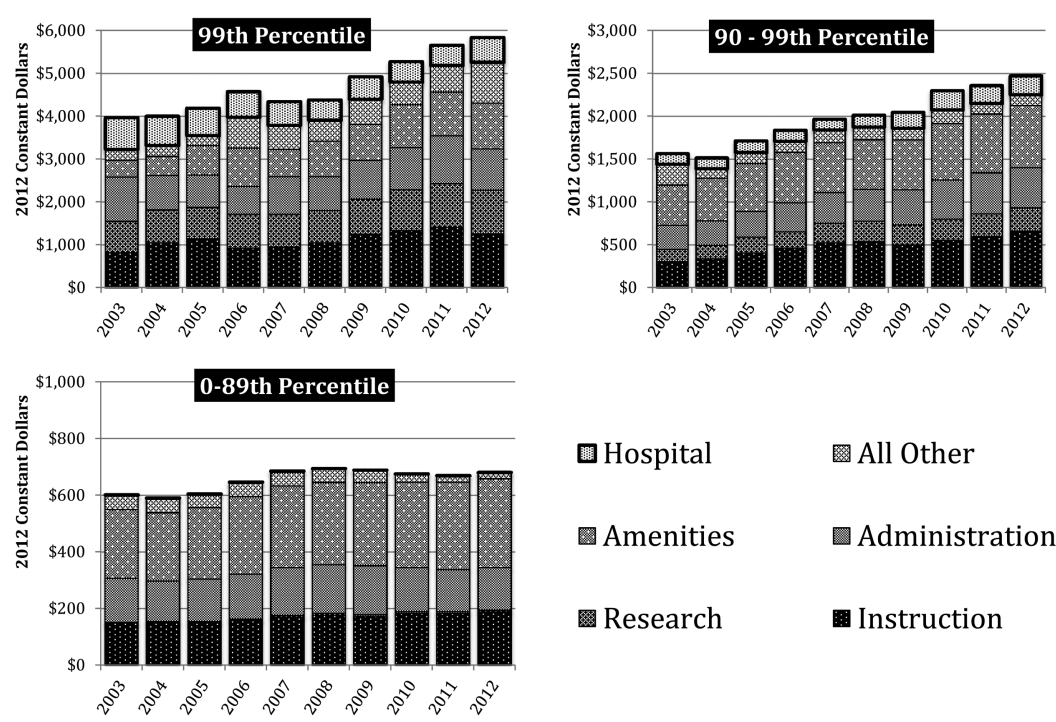

\begin{tabular}{|c|c|}
\hline 䧃 Hospital & 圆 All Other \\
\hline Amenities & $\square$ Administration \\
\hline 网 Research & 国 Instruction \\
\hline
\end{tabular}

Source: IPEDS.

Note: Quantiles are for institutions' 2003 endowment wealth. Spending per student is the total spending for the quantile over the total FTE student enrollment per quantile.

Figure 5. Private institutions' spending per student on interest by purpose of debt and percentiles for endowment wealth.

purposes at private institutions in the bottom $90 \%$ of endowment wealth. Interest costs for amenities as a share of all interest costs increased from 36.2 to $44.3 \%$ at institutions in the former quantile and from 41.7 to $46.0 \%$ for the latter quantile. ${ }^{14}$ Comparable data are not available for public systems prior to 2010. The distribution of interest spending by purpose, however, is comparable at public institutions in those years for which data are available.

The high level of reported interest spending on auxiliary services indicates that less wealthy public and private colleges are using institutional debt towards maximizing commercial revenues, while at the wealthiest institutions it was oriented toward maximizing financial revenues. Scholars have argued that colleges expanded amenities to boost commercial revenue by attracting more students willing to pay higher tuition and fees (Jacob et al., 2013). In 2003, Clare Cotton, president of the Association of Independent Colleges and Universities in Massachusetts at the time, told the New York Times, 'it's exactly the psychology of an arms race. From the outside it seems totally crazy, but from the inside it feels necessary and compelling' (Winter, 2003). As we see in Figure 5, borrowing for capital investments offered a potentially potent resource for staying competitive in the college amenities arms race.

14 For public systems, data are only available to disaggregate interest spending by purpose from 2010 to 2012. As such, we cannot assess trends in interest spending over time in the case of publics. In all years for which data are available, however, interest costs for amenities made up the largest area of average interest costs for public systems in all years across all of the quantiles we use for endowment wealth. The average share of interest spending for amenities purposes at public systems ranged from 46.8 to $48.9 \%$ for the 99 th percentile, from 52.7 to $54.4 \%$ for the 90 th to 98 th percentiles, and from 35.2 to $36.2 \%$ for the bottom 90 percentiles. 


\section{Proprietary colleges and profits as the cost of equity investment}

The above sections showed how endowment revenues and interest costs have assumed a greater role within the traditional public and non-profit subsectors. In this section, we focus on the rapid growth of investor-owned, for-profit colleges as a third form of financialization within higher education. Whereas public and non-profit colleges rely on credit and endowment capital, proprietary colleges principally rely on a different type of financing: equity capital from investors. The operating profits generated by these institutions to satisfy equity investors can thus be thought of as the financing cost for proprietary colleges' capitalization. In this section, we track the for-profit subsector's contribution to higher education financialization by estimating the costs of financing higher education with investors' equity. Specifically, we chart annual net operating profits among those institutions owned by publicly traded and private equity firms.

\subsection{Equity capital and proprietary college growth}

As we saw in Section 2.2 and Figure 1, for-profit colleges became the fastest growing type of higher education institution at the end of the 1990s. IPEDS data show that enrolments at proprietary colleges expanded by $306.5 \%$ in 13 years from 429183 in 2000 to 1.7 million in 2012. For comparison, the public college sector had the next highest growth rate, increasing by $31.0 \%$ from 2000 to 2012 .

Small, privately-held proprietary colleges long filled a niche role within the higher education ecology. Traditionally, these firms specialized in 1- or 2-year technical and vocationaltraining programs. They were typically owned and operated locally. In 1990 there was not a single publicly-traded higher education firm. During the 1990s, however, proprietary colleges attracted growing interest from private financiers. The Apollo Group, which owns the University of Phoenix, first went public in 1991, followed by DeVry in 1994 and Educational Management Corporation in 1996. Soon, corporate-holding companies and private equity firms began entering the higher education sector. They often did this by assuming control of existing proprietary or non-profit schools that already possessed an accreditation.

From 2003 to 2012, the number of for-profit college companies owned by private equity firms increased from 18 to 61 and the number of publicly traded for-profit college companies increased from 10 to 21 . The number of campuses owned by private equity companies accordingly increased from 84 to 195 and the number of campuses owned by publicly traded forprofit college companies increased from 237 to 536 . Figure 6 shows that the radical growth of the for-profit sector was driven most by publicly traded firms and private firms financed by private equity. Enrolment at closely held college firms grew by just $76 \%$ from 193146 in 2000 to 339843 in 2012. Enrolment at private equity financed college firms, however, grew by $1035 \%$ from 24492 in 2000 to 277979 in 2012 . Enrolment at publicly traded college firms increased by $433 \%$ from 211545 in 2000 to 1.1 million in 2012. (A portion of the publicly traded growth was driven by previously private equity financed college firms that went public.) By 2011, colleges owned by publicly traded or private equity firms together accounted for over $75 \%$ of enrolments at proprietary colleges.

Investors instituted a scale-based, rapid-growth business model that sought to corral the maximum number of tuition payers through the doors (or online portals) while maintaining 


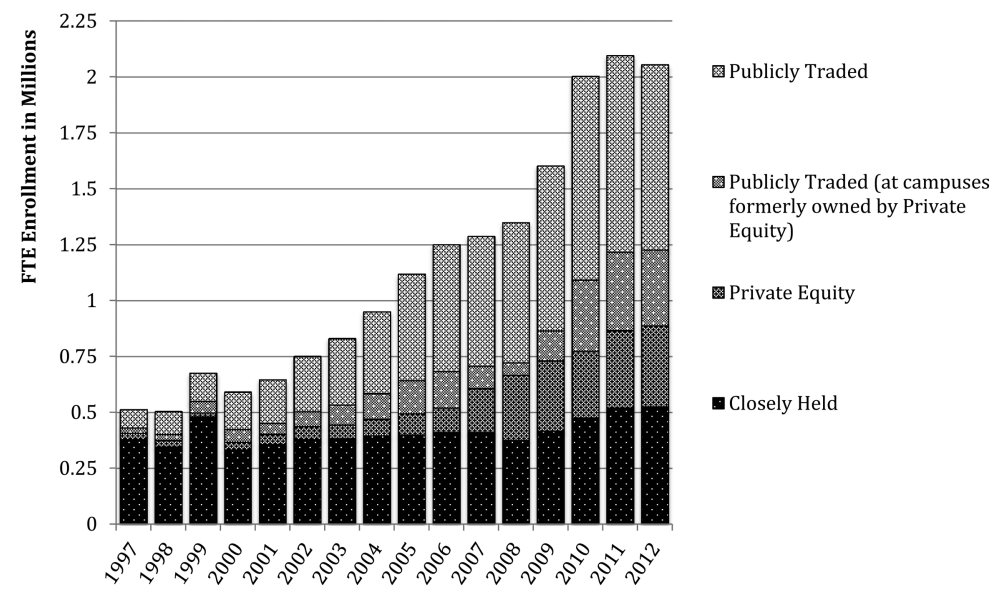

Source: Original database by authors combining data from IPEDS, ThomsonOne, unpublished Senate HELP Committee documents, firm 10-k statements, and college online course catalogs.

Figure 6. For-profit enrolment by college ownership form.

minimal marginal costs. The case of Education Management Corporation (EDMC) provides an illustrative example of this transformation (US Senate Committee on Health Education Labor and Pensions, 2012). EDMC was founded in 1962, and had long been reputed as one of the higher quality proprietary college companies. In 2006, EDMC was taken over by a private equity consortium led by Goldman Sachs along with Providence Capital Partners and Leeds Capital. Goldman and its partners installed new executives who promptly reallocated resources from instruction to marketing and recruitment. Total enrolment across EDMC's brands, which include Argosy University, South University, Brown Mackie College and the Arts Institutes, more than doubled between 2006 and 2010. By 2011, colleges in which Goldman Sachs was the dominant owner enrolled over 150000 students, captured over $\$ 486$ million in federal Pell Grant funds, and netted an operating profit of over $\$ 501$ million. ${ }^{15}$ As we will discuss later, however, enrolments at for-profits have declined since 2011 amid reregulation, lawsuits and a political backlash against perceived predatory practices.

\subsection{Measuring proprietary college profits as the cost of equity financing}

Below we estimate the cost of using equity capital to finance higher education expansion by charting the total annual net operating profits among those institutions owned by publicly traded and private equity firms.

Figure 7 shows the proprietary college net annual operating profits from 2003 to 2012, expressed in constant (base 2012) dollars. Over the decade, the size of annual net operating profits increased five-fold from over one billion dollars in 2003 to just over five billion dollars in 2011 before falling back to three billion dollars in 2012 as enrolments failed to keep pace with expanded capacity.

15 See EDMC 2012 Annual Report. The private equity consortium reoffered EDMC on the NASDAO stock exchange in 2009. As of September 2013 Goldman continued to hold a 43 percent ownership stake. 


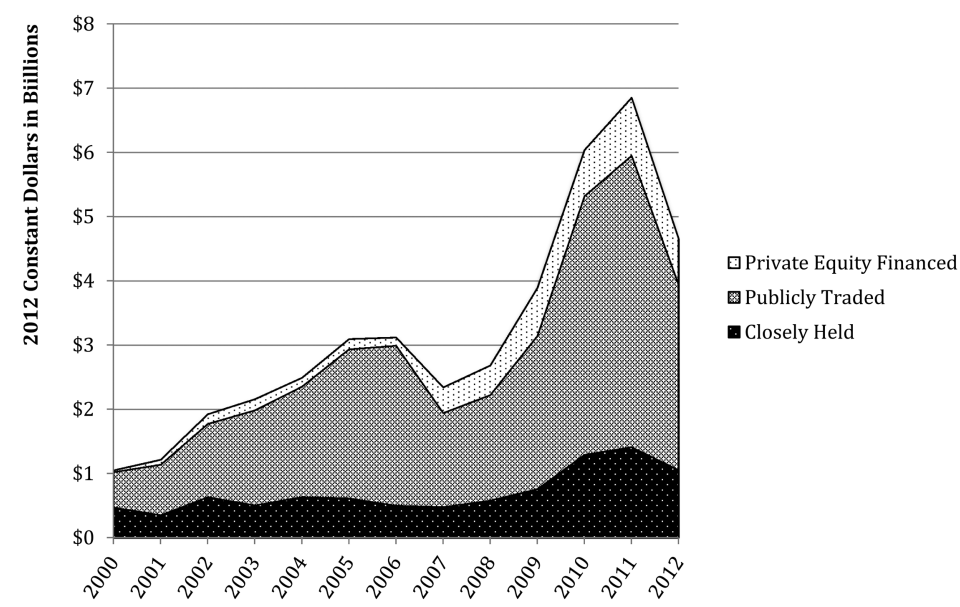

Source: Original database by author combining data from IPEDS, ThomsonOne, unpublished Senate HELP Committee documents, firm 10-k statements, and college online course catalogs.

Figure 7. Operating profits for proprietary colleges.

An analysis of income data reveals that the proprietary college industry was characterized by very high margins: gross margins among the publicly traded firms in this study averaged $\sim 55 \%$ during the period under study. ${ }^{16}$ This is significantly higher than the $33 \%$ average gross margin across 99 major industries in the US (standard deviation: $14 \%$; median: $31 \%$ ). ${ }^{17}$

It is worth noting that the decline in total profits among proprietary schools after 2011 resulted from concerted policy shifts. The entire sector contracted after the Obama administration tightened rules for proprietary schools to recruit and enrol federal funding recipients. The resulting decline in the share of higher education spending that goes to profits for equity investors represents a real reversal in this form of financialization. We discuss the role of policy further in the discussion section below.

\section{Student loan debt and interest payments}

As colleges increased tuition, room and board costs, they increasingly assumed the role of student loan broker to arrange financing for households to pay for these costs. As discussed at the end of Section 2, the federal government increasingly acted as the direct lender in these transactions. On the other side of these loan transactions, households increasingly took on the role of borrower. As a result, household spending on student loan interest payments increased more persistently than for-profit financing costs or any of the other higher education financing costs that we have examined. In this section, we explain our estimation that household spending on interest on student loans increased from $\$ 14$ billion in 2003 to $\$ 34$ billion in 2012. As a

16 Author calculations using 10-K income statements for publicly traded for-profit colleges.

17 Authors' calculation using industry average margins dataset acquired from Aswath Damodaran (http://pages.stern.nyu.edu/ adamodar/). Gross margins are calculated as EBITDA SG\&A/Sales. 


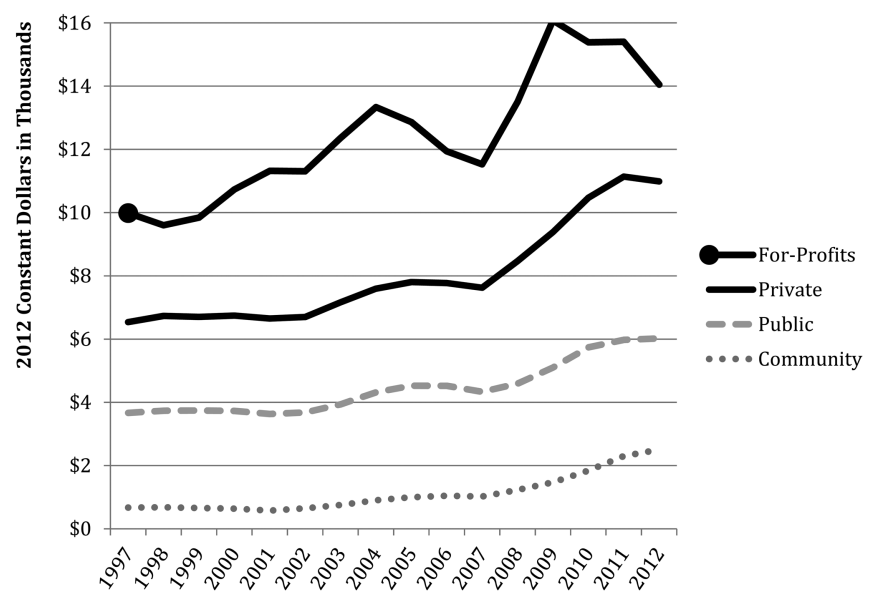

Source: College Board Trends in Student Aid Loan Origination Data and IPEDS Enrollment Data. Loan origination per student is the total loan origination for the given sector over the total FTE student enrollment sector.

Figure 8. Annual student loan origination per FTE student.

result, we estimate that student loan interest payments increased from 14 to $20 \%$ as a share of all household spending on higher education. ${ }^{18}$

\subsection{Increased student loan borrowing as the driver of student loan interest spending}

Figure 8 shows that student loan borrowing per FTE student ${ }^{19}$ increased across all sectors after 2002. The average borrowing began to increase 2 years earlier at for-profits, however, and borrowing increased most at for-profits and non-profit private colleges. Increased borrowing at for-profits and non-profit privates widened a disparity over public institutions.

For the years since 2003, we can disaggregate average borrowing per full-time freshman student (this IPEDS measure does not include borrowing by parents which is included in Figure 8) by quantiles for public and private colleges' endowment wealth (see Figure 9). When we do so, we see a widening gap between low student loan burdens at the wealthiest private institutions and greater borrowing across other institutions. Average annual freshman borrowing actually declined at private colleges in the 99th percentile for endowment wealth, from $\$ 1601$ per student (not borrower) in 2003 to $\$ 1082$ in 2012. The highest levels of student loan borrowing occurred in the bottom $89 \%$ of private institutions where average borrowing per student increased from under $\$ 3549$ to more than $\$ 5110$. The increase in borrowing was more uniform across public systems where average borrowing increased across all endowment wealth quantiles but also increased most at systems in the bottom $89 \%$ for endowment wealth.

18 We estimate total household spending on higher education by adding total household spending on student loan interest to total household spending on tuition and fees from IPEDS. We do not include spending on room and board in this estimate because we lack adequate data.

19 These figures are per FTE student, not per borrower, because aggregate borrowing amounts are available by sector for the full time series from the College Board but aggregate numbers of borrowers are not. 


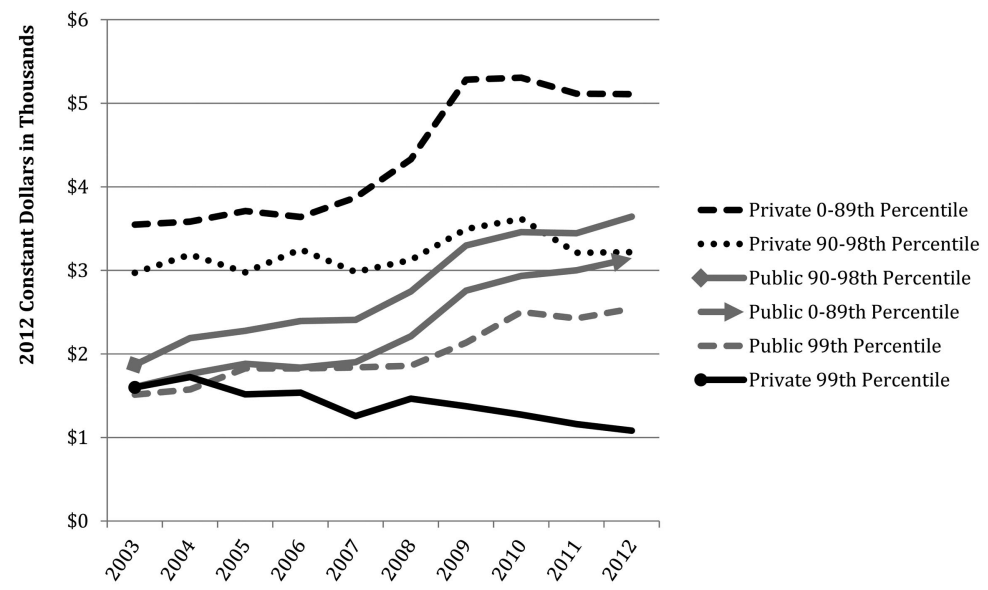

Source: IPEDS.

Note: *Unlike in Figure 9, borrowing by students' parents is not included here. Community-college-only systems, military institutions and institutions that do not enroll undergraduates are excluded. Quantiles are for institutions' 2003 endowment wealth and are calculated for each sector separately. Borrowing per full-time freshman is the total borrowing by full-time freshmen for the quantile over total full-time freshmen enrollment the quantile.

Figure 9. Borrowing per full-time freshman bachelor degree student by sector and endowment wealth quantiles.

\subsection{Increasing student loan interest spending}

These dramatic increases in borrowing have led to large increases in household spending on interest for student loans. Figure 10 shows the total annual estimated interest costs borne by households for student loans, broken down by loan type. Our analysis includes all federal loans and non-federal loans except for the small federal Perkins loan program. Shifts in the mix of loan costs over time reflect changes in their relative interest rates, as well as changes in their relative volume of origination. ${ }^{20}$

The dotted line in Figure 10 shows that spending on interest increased from 14 to $20 \%$ as a share of total household spending on higher education. ${ }^{21}$ The radical jump in interest as a share of household spending occurred entirely from 2004 to 2007 and reflects a lagged increase in loan repayment after the counter cyclical surge in student loan borrowing during the 2001 recession. Repayment of federal student loans, however, does not begin until the end of a sixth month grace period after higher education enrolment ends for a borrower. As such, borrowers who are just entering a 4-year degree program may go 4 years or more before entering repayment. Because our estimates end in 2012, they do not include the surge in student loan interest payments that we should expect from surges in borrowing since 2007.

20 The share of payments due to subsidized Stafford loans declined after 2008 because the federal government reduced the interest rate for these loans. So, even though origination of subsidized Stafford loans continued to grow, total annual interest costs for these loans actually decreased. Interest rates for other federal loan types remained steady for new cohorts while the total origination of all federal loan types increased in real dollars.

21 Ibid. 


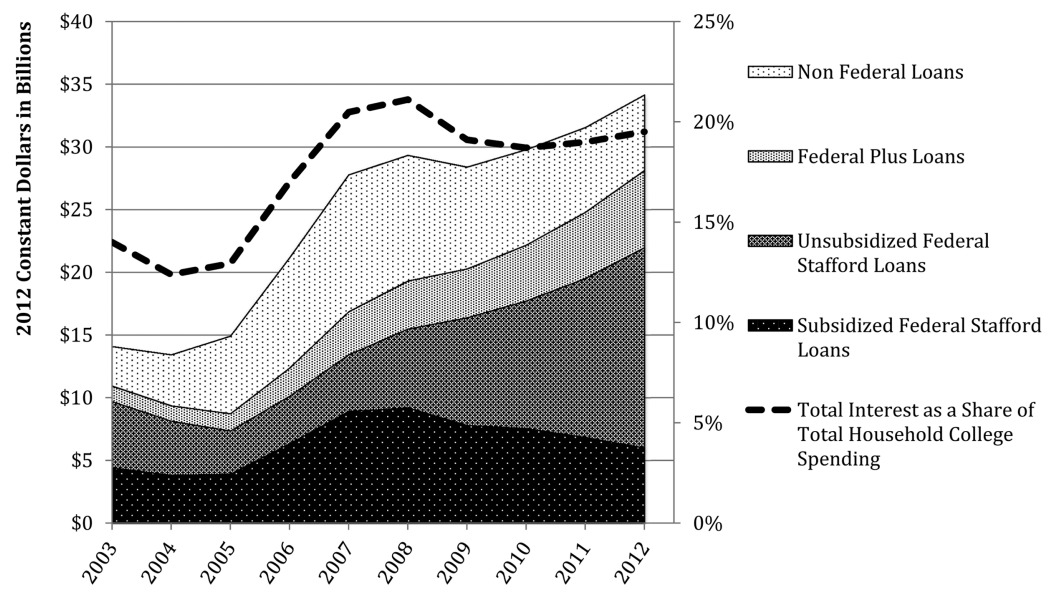

Source: Author calculations using origination data from the College Board, estimates of time in repayment period from the Department of Education, private student loan interest rate estimates from the Consumer Financial Protection Bureau and interest rate data from the Department of Education published by FinAid.org. Total household spending was estimated by summing total household spending on tuition and student loan interest and does not include household spending on other college expenses such as housing. See Data Appendix for a methodological explanation of the calculations.

Figure 10. Interest payments on student loans by loan type and interest as a share of total household college spending.

The case of federal student loans reinforces how examining financing costs can reveal forms of financialization that are invisible using profit-accumulating measures. The federal government terminated the Federal Family Education Loan (FFEL) loan program for guaranteeing federal loans that private banks fund in exchange for profits on interest. So, while outstanding FFEL loan debt remained at $\$ 423$ billion in 2013, no new FFEL loans have been issued since 2010. In addition, private loan issuance by banks without federal backing collapsed after the 2008 financial crisis to just $\$ 6$ billion a year or less than $5 \%$ of all new student loan origination (Consumer Financial Protection Bureau and US Department of Education, 2012, p. 3). Instead, student loans funded directly by the federal government have become overwhelmingly the largest source of lending with more than $\$ 617$ billion in outstanding loans by 2013 when overall student debt topped $\$ 1$ trillion (Congressional Budget Office, 2013). Yet neither federal student loan financing costs nor federal government revenues from student loans appear in traditional measures of profit accumulation from financial transactions.

\section{Quantifying the costs of higher education financialization}

This article has shown that financialization has been multifaceted for US higher education as a hybrid field of social provision that includes for-profit, non-profit and public organizations. We have thus far detailed how revenue and costs from financial transactions tended to change according to the ownership forms and wealth strata of the colleges involved. Now we can quantify the total economic costs of increasing reliance on all four of the key higher education financial transactions together. We can also compare the aggregate returns and costs from each transaction type. In doing so, we will show that rising finance costs far surpassed 


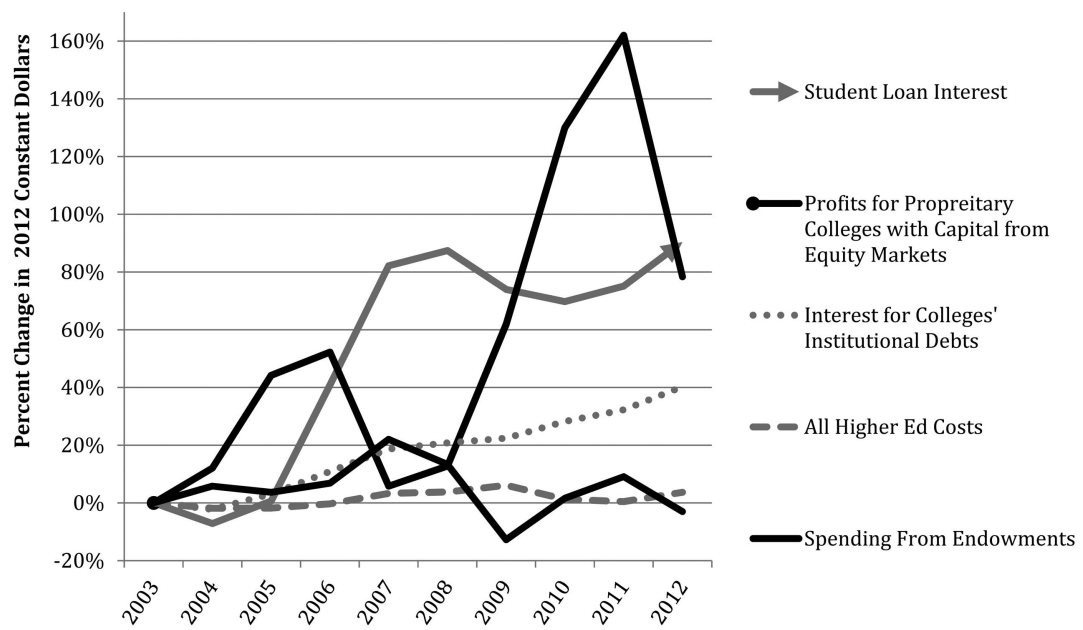

Source: Author calculations using data from IPEDS, income sheets for publicly traded for-profit colleges, the College Board, Department of Education, Consumer Financial Protection Bureau, and FinAid.org. See text and Data Appendix for further explanation.

Figure 11. Change in higher education costs per FTE student since 2003.

increases in financial returns. We also find that the costs of financial transactions increased much more for households than for colleges.

Figure 11 compares the relative growth in total real per student expenditure with growth in each of the three costs of financial transactions that we discussed above. From 2003 to 2012 these costs increased on a per student basis while overall spending on higher education per student remained flat. Together, annual higher education financing costs increased from $\$ 21$ to $\$ 48$ billion. Financing costs across all years totalled just over $\$ 350$ billion. While this shift was large, it was neither uniform nor linear for all three of the principal higher education financing costs.

Interest spending per student for colleges' institutional borrowing increased steadily and throughout public, private and community colleges. When measured per student for all FTE students, these costs increased by $40 \%$ from $\$ 476$ in 2003 to $\$ 668$ in 2012. (This measurement differs slightly from those reported in Section 5 which measured per student increases by enrolment at only those colleges reporting institutional interest costs. See Supplementary material, Appendix for further details). In contrast, profits per student for proprietary colleges financed with equity capital increased radically by $162 \%$ from 2003 to 2011 before collapsing (again, we measure this cost per student for all US students, not just those enrolled at proprietary colleges - this represents how the relative growth in scale of the proprietary sector affects overall costs for the entire higher education system). Average education loan interest costs per student saw the largest persistent increase of $90 \%$ from 2003 to 2012.

The turn to finance also provided growing resources for higher education through returns on endowment investments. Annual spending from endowments increased from $\$ 16$ to $\$ 20$ billion. We estimate that colleges' spent $\$ 188$ billion from endowment-generated revenue 
during our period. ${ }^{22}$ However, this figure is considerably lower than the $\$ 350$ billion in financing costs that we have estimated. Moreover, financial revenues from endowments have been concentrated in a small fraction of the overall higher education system. As a result, spending from endowments remained essentially flat as a share of all university spending at $4 \%$. In contrast, the costs of the three other financial transactions increased from 5 to $9 \%$ as a share of all higher education expenditures.

The above comparisons show that financialization has manifested itself more broadly in the increasing share of higher education expenditures that go to financing costs, which increased from 5 to $9 \%$. In a sense, one could say that colleges benefited most broadly from financialization through the use of student loans to pay for increasing tuition and student services costs. This use of financial transactions, however, came at a radically increased expense to households. In some instances, this offset state funding reductions. In comparison to financing arrangements that rely more on direct state appropriations funded by tax revenue; however, it is fair to say that financialization drained more resources from higher education than it generated for the sector.

\section{Conclusions}

Our study holds implications for both economic sociology and the sociology of higher education. By adopting new conceptualizations and measurement strategies, we bridge accumulation-based perspectives (Arrighi, 1994; Krippner, 2011) with the need to consider the different financial transaction roles assumed by the broader array of actors who populate hybrid arenas of public-private social provision (van der Zwan, 2014). Using this framework, we have documented the growing role of finance across the heterogeneous subsectors of US higher education: traditional public and non-profit educational providers have come to rely more heavily on financially mediated flows of investment revenue and debt-funded capital. Meanwhile, equity capital fuelled the growth of an explicitly financialized subsector of forprofit providers. Finally, educational consumers have been saddled with growing interest payments as debt balances grew.

Although financiers have profited enormously from the increasing the use of credit instruments, the financialization of higher education cannot be reduced to profit accumulation or rent extraction. Nor is the process of financialization reducible to privatization of public provision. In fact the state has been one of the main participants in the transformation we describe. Before 2010, the majority of student loans were privately financed at least in part. Now, the federal government directly finances and administers more than $90 \%$ of US student loans, and it is the largest recipient of interest income from student loan payments. It is a testimony to the active role of the state in financialization that the US Department of Education has been one of the fastest growing consumer creditors in the US since 2010. This transformation of student lending underscores the growing role of financial funding mechanisms even for redistributive social policies (Krippner, 2011; Quinn, 2012).

Our findings raise many questions and open several lines of future research. First, we have deliberately said little about the causes of the trends documented above. Why have colleges

22 This number is higher than the sum of endowment spending reported earlier because we include here estimated spending based on average annual endowment spending rates by sector for those systems and institutions that did not report annual spending rates. 
increasingly taken on the roles of borrower, investor or both? Organizational studies might examine how the adoption of financialized practices and strategies is embedded in particular networks, professional projects and conceptions of control. For instance, we have some evidence from case studies that financialized strategies were transmitted through networks and board interlocks between investment banks, at least at the University of California (Eaton et al., 2013). Future work might probe the migration of personnel from financial firms to other fields.

Our findings also raise a variety of further questions about the broader consequences of financialization for households, universities and social stratification. Studies suggest that financialization in the private sector has shifted organizational power and governance, heightened stratification and allocated resources away from productive investments (Orhangazi, 2008; Tomaskovic-Devey and Lin, 2011; Goldstein, 2012; Lin and Tomaskovic-Devey, 2013). To what extent have comparable consequences been felt in higher education? How does financialization affect educational outcomes and educational stratification, either by reorienting organizational priorities or redistributing resources?

We might expect the effects to be especially pronounced within the for-profit sector, where financialization entails direct organizational control over educational providers. As Wall Street took over for-profits, investors demanded higher returns, which shifted resources from instruction to recruitment (US Senate Committee on Health Education Labor and Pensions, 2012). We have also shown that students' average student loan borrowing increased fastest and to the highest levels at for-profits. Yet for-profits and the poorest public institutions disproportionately enrol minorities and students from lower social class backgrounds. Together, these aggregate facts suggest that the financialization of higher education may play a significant direct role in exacerbating educational and economic stratification. Future research should explore this possibility using household-level data and plausible counterfactual conditions.

We can also expect significant (though perhaps less dramatic) effects among public and non-profit institutions. As shown above, borrowed capital has disproportionately funded investments in non-instructional commercial activities, including amenities. Scholars have tended to explain the trend towards amenities spending as a marketing tactic to attract tuitionpaying students (Armstrong and Hamilton, 2013; Jacob et al., 2013). However, the shifting relationship between universities and financial markets may also play an independent role. Resource-dependence theory suggests that the power of financial managers and experts within universities should increase as their organizations become more dependent on capital markets. The need to appease capital market audiences such as ratings agencies pushes organizations to have to focus more on revenues in order to continue accessing low-cost capital. Moody's ratings methodology, for example, accounts for a higher education institution's 'pricing power' in terms of high student demand and statutory flexibility to increase tuition, its 'operational performance' in terms of the diversity of its revenue streams and control over expenditures on faculty, and its 'capital investment' in facilities that draw in additional revenues (Moody's Investor Service, 2011). Increasing dependence on financial markets may thereby bias resources towards revenue-generating commercial projects and increased student loan origination. In this way, bond markets promote organizational behaviours that may be at odds with the goals of cost-efficient social provision in areas like higher education. 
A related question is to what extent funding higher education through financial transactions may exacerbate stratification in resources across institutions (Muller and Shavit, 1998; Brewer et al., 1999; but for a word of caution, see Gerber and Cheung, 2008)? Our findings imply that wealthy institutions seized on the opportunities provided by financialization by using debt to effectively bolster investment returns from endowments. In contrast, poorer public and private institutions were not in a position to offset increasing interest costs from institutional debts with increased financial returns from endowments.

Finally, there is a need for cross-national comparative research on the scope and consequences of financialization in higher education. More than 70 countries are known to have student loan programs. In contrast to the USA, however, most nations have programs that are significantly subsidized to offer low or zero interest rates and multiple provisions for avoiding excessive repayment burdens (Shen and Ziderman, 2009). Under these conditions, student loan programs may help to increase college attainment by covering tuition or the cost of living without exposing students to risky credit obligations that may exceed future income benefits. This contrast suggests that cross-national studies will offer insights into how particular forms of financial transformations, either through student loans or through capital financing for educational institutions, may help or hinder educational policy objectives.

\section{Supplementary material}

Supplementary material is available at SOCECO online.

\section{Acknowledgements}

We would like to thank members of the UC Berkeley Center on Culture, Organization, and Politics seminar for their valuable feedback.

\section{Funding}

This research was supported by a research gift from the American Federation of Teachers.

\section{References}

Armstrong, E. A. and Hamilton, L. T. (2013) Paying for the Party: How College Maintains Inequality, Cambridge, MA, Harvard University Press.

Arrighi, G. (1994) The Long Twentieth Century: Money, Power, and the Origins of Our Times, New York, Verso.

Avery, C. and Turner, S. (2012) 'Student Loans: Do College Students Borrow Too Much-Or Not Enough?', The Journal of Economic Perspectives, 26, 165-192.

Brewer, D. J., Eide, E. R. and Ehrenberg, R. G. (1999) 'Does It Pay to Attend an Elite Private College? Cross-Cohort Evidence on the Effects of College Type on Earnings', Journal of Human Resources, 34, 104-123.

Brown, M., Haughwout, A., Lee, D., Scally, J. and van der Klaauw, W. (2014) Measuring Student Debt and Its Performance, New York, NY, Federal Reserve Bank of New York Staff Reports.

Brown-Collier, E. K. (1998) 'Johnson's Great Society: Its Legacy in the 1990s', Review of Social Economy, 56, 259-276. 
Congressional Budget Office. (2010) Tax Arbitrage by Colleges and Universities, Washington, DC, Congress of the United States.

Congressional Budget Office. (2013) Options to Change Interest Rates and Other Terms on Student Loans, Washington, DC, Congress of the United States.

Consumer Financial Protection Bureau and U.S. Department of Education. (2012) Private Student Loans: Report to the Senate Committee on Banking, Housing, and Urban Affairs, the Senate Committee on Health, Education, Labor, and Pensions, the House of Representatives Committee on Financial Services, and the House of Representatives Committee on Education and the Workforce, Washington, DC, Consumer Finance Protection Bureau.

Davis, G. F. (2009) Managed by the Markets: How Finance Re-Shaped America, Oxford, Oxford University Press.

Deming, D. J., Goldin, C. and Katz, L. F. (2012) 'The For-Profit Postsecondary School Sector: Nimble Critters or Agile Predators?', Journal of Economic Perspectives, 26, 139-164.

Eaton, C., et al. (2013) 'Swapping Our Future: How Students and Taxpayers Are Funding Risky UC Borrowing and Wall Street Profits', Berkeley Journal of Sociology, 57, 177-199.

Ehrenberg, R. G. (2000) Tuition Rising, Cambridge, MA, Harvard University Press.

Epstein, G. A. (2005) Financialization and the World Economy, Northampton, MA, Edward Elgar Publishing.

Fligstein, N. (1993) The Transformation of Corporate Control, Cambridge, Harvard University Press. Fligstein, N. (2001) The Architecture of Markets: An Economic Sociology of Twenty-First-Century Capitalist Societies, Princeton, Princeton University Press.

Fligstein, N. and Goldstein, A. (2015) 'The Emergence of a Finance Culture in American Households, 1989-2007: Some Preliminary Evidence', Socio-Economic Review, 13, 525-548.

Geiger, R. L. (2004) Knowledge and Money: Research Universities and the Paradox of the Marketplace, Stanford, CA, Stanford University Press.

Geiger, R. L. (2006) 'The Quest for 'Economic Relevance' by US Research Universities', Higher Education Policy, 19, 411-431.

Gerber, T. P. and Cheung, S. Y. (2008) 'Horizontal Stratification in Postsecondary Education: Forms, Explanations, and Implications', Annual Review of Sociology, 34, 299-318.

Goldstein, A. (2012) 'Revenge of the Managers Labor Cost-Cutting and the Paradoxical Resurgence of Managerialism in the Shareholder Value Era, 1984 to (2001)', American Sociological Review, 77, 268-294.

Hacker, J. S. (2002) The Divided Welfare State: The Battle Over Public and Private Social Benefits in the United States, New York, NY, Cambridge University Press.

Houle, J. N. (2014) 'A Generation Indebted: Young Adult Debt across Three Cohorts', Social Problems, 61, 448-465.

Jacob, B., McCall, B. and Stange, K. M. (2013) ‘College as Country Club: Do Colleges Cater to Students' Preferences for Consumption?' National Bureau of Economic Research working paper \# 18745.

Krippner, G. R. (2005) 'The Financialization of the American Economy', Socio-Economic Review, 3, 173-208.

Krippner, G. R. (2011) Capitalizing on Crisis, Cambridge, MA, Harvard University Press.

Langley, P. (2008) The Everyday Life of Global Finance: Saving and Borrowing in Anglo-America: Saving and Borrowing in Anglo-America, New York, NY, Oxford University Press.

Lin, K.-H. and Tomaskovic-Devey, D. (2013) 'Financialization and US Income Inequality, 19702008,' American Journal of Sociology, 118, 1284-1329.

Martin, R. (2002) Financialization of Daily Life, Philadelphia, PA, Temple University Press.

Mettler, S. (2014) Degrees of Inequality: How Higher Education Politics Sabotaged the American Dream, New York, Basic Books.

Moody's Investor Service. (2011) 'Rating Methodology: US. Not-for-Profit Private and Public Higher Education', Moody's Investor Service, August 26. 
Morgan, K. J. and Campbell, A. L. (2011) The Delegated Welfare State: Medicare, Markets, and the Governance of Social Policy, New York, NY, Oxford University Press.

Muller, W. and Shavit, Y. (1998) 'The Institutional Embeddedness of the Stratification Process: A Comparative Study of Qualifications and Occupations in Thirteen Countries'.

National Association of College and University Business Officers (NACUBO). (2013) NACUBO Endowment Study Series (1977-2013), Washington, DC, National Association of College and University Business Officers.

National Center for Education Statistics. (2014) 'IPEDS Data Center', Integrated Post-Secondary Education Data System, nces.ed.gov/ipeds/datacenter.

Nau, M. (2013) 'Economic Elites, Investments, and Income Inequality', Social Forces, 92, 437-461.

Orhangazi, Ö. (2008) 'Financialisation and Capital Accumulation in the Non-Financial Corporate Sector: A Theoretical and Empirical Investigation on the US Economy: 1973-2003', Cambridge Journal of Economics, 32, 863-886.

Pacewicz, J. (2013a) 'Regulatory Rescaling in Neoliberal Markets', Social Problems, 60, 433-456.

Pacewicz, J. (2013b) 'Tax Increment Financing, Economic Development Professionals and the Financialization of Urban Politics', Socio-Economic Review, 11, 413-440.

Piketty, T. (2014) Capital in the Twenty-First Century, Cambridge, MA, Harvard University Press. Powell, W. W. and Owen-Smith, J. (1998) 'Universities as Creators and Retailers of Intellectual Property: Life-Sciences Research and Commercial Development'. In To Profit or not to Profit: The Commercial Transformation of the Nonprofit Sector. Cambridge, Cambridge University Press.

Quinn, S. (2012) 'The hidden Credit State: A Sociology of Federal Credit Programs in the United States', Unpublished paper, Department of Sociology, University of Washington.

Quinterno, J. (2012) The Great Cost Shift: How Higher Education Cuts Undermine the Future of the Middle Class, New York.

Rhoades, G. (1990) Political Competition and Differentiation in Higher Education, New York, Columbia University Press New York.

Shen, H. and Ziderman, A. (2009) 'Student Loans Repayment and Recovery: International Comparisons', Higher Education, 57, 315-333.

Slaughter, S. and Leslie, L. L. (1997) Academic Capitalism: Politics, Policies, and the Entrepreneurial University, Baltimore, MD, Johns Hopkins University Press.

Stevens, M. L., Armstrong, E. A. and Arum, R. (2008) 'Sieve, Incubator, Temple, Hub: Empirical and Theoretical Advances in the Sociology of Higher Education', Annual Review of Sociology, $34,127-151$.

The College Board. (2013) 'Total Student Aid and Nonfederal Loans in 2012 Dollars over Time', Trends in Student Aid, http://trends.collegeboard.org/student-aid/figures-tables/total-aidnonfederal-loans-current-constant-dollars-over-time.

Tomaskovic-Devey, D. and Lin, K.-H. (2011) 'Income Dynamics, Economic Rents, and the Financialization of the US Economy', American Sociological Review, 76, 538-559.

U.S. Senate Committee on Health Education Labor and Pensions. (2012) For Profit Higher Education: The Failure to Safeguard the Federal Investment and Ensure Student Success, Washington, DC, United States Senate.

Van der Zwan, N. (2014) 'Making Sense of Financialization', Socio-Economic Review, 12, 99-129. Weerts, D., Sanfordeah, T. and Reinert, L. (2012) College Funding in Context: Understanding the Difference in Higher Education Appropriations across the States, New York, NY, Demos.

Winston, G. C. (1999) 'Subsidies, Hierarchy and Peers: The Awkward Economics of Higher Education', The Journal of Economic Perspectives, 13, 13-36.

Winter, G. (2003) 'Jacuzzi U.? A Battle of Perks to Lure Students', New York Times, October 5.

Zorn, D., Dobbin, F., Dierkes, J. and Kwok, M.-S. (2005) 'Managing Investors: How Financial Markets Reshaped the American Firm'. In Knorr-Centia, Karin and Alex Preda (eds) The Sociology of Financial Markets, New York, NY, Oxford University Press, pp. 269-289. 